\title{
Analysis of The Effect of Capital Adequacy Ratio (CAR), Non Performing Loan (NPL), Net Interest Margin (NIM), Operating Expenses to Operating Income (BOPO), and Loan to Deposit Ratio (LDR) on Profitability of State-Owned Banks in The 2009-2018 Period
}

\author{
${ }^{1}$ Chintia Sianturi, ${ }^{2}$ Dadan Rahadian \\ ${ }^{*}{ }^{1,2}$ School of Economics and Business, Telkom University, Jl. Telekomunikasi Terusan Buah Batu, Bandung, 40257 \\ ${ }^{1}$ chintiasianturi@gmail.com, ${ }^{2}$ dadan.rahadian@telkomuniversity.ac.id \\ DOI: 10.29322/IJSRP.10.07.2020.p10384 \\ http://dx.doi.org/10.29322/IJSRP.10.07.2020.p10384
}

\begin{abstract}
Banks have a vital role in the economic and financial system of a country. They play roles in managing, controlling, and protecting public funds to create a healthy financial industry. Therefore, the bank needs to consider and maintain its condition. It can be seen from the assessment of the risk and performance of the bank. The assessment can use information in the financial statement and its financial ratio analysis. The financial ratio analysis can help business stakeholders including bank owners, bank managers, the public who use the services, and Bank Indonesia as the bank's supervisory authority. This research aims to identify the effect of Capital Adequacy Ratio (CAR), Non-performing Loans (NPL), Net Interest Margin (NIM), Operating Expenses to Operating Income (BOPO), and Loan to Deposit Ratio (LDR) on the profitability of the bank in the $2009-2018$ period proxied by Return on Assets (ROA). This research used a quantitative approach. The sample was selected using a non-probability sampling technique in which it involved all state-owned banks, namely Bank Rakyat Indonesia, Bank Mandiri, Bank Negara Indonesia, and Bank Tabungan Negara. The data were analyzed using panel data regression analysis. The result of this study indicated that CAR, NPL, NIM, BOPO, and LDR significantly and simultaneous affect ROA. Further, CAR, BOPO, and LDR partially and significantly have a negative effect on profitability (ROA). In detail, NIM has a significant positive effect on profitability (ROA) and NPL does not affect profitability (ROA) in the state-owned banks in the 2009-2018 period.
\end{abstract}

Index Terms- CAR, NPL, NIM, BOPO, LDR, and ROA

\section{INTRODUCTION}

Banks play a crucial role in the economic and financial system of a country. The Law of the Republic of Indonesia Number 10 of 1998 concerning banking explains that banks are business entities collecting funds from the public in the form of savings and distribute the funds to the public in the form of credit and or other forms to improve their life. Therefore, banks have a crucial role as they help to improve the economy of a country.

Referring to the Bank Indonesia Regulation Number 13/1/PBI/2011 concerning Risk-Based Bank Rating of public banks explain that it is an assessment of the performance and risks of a bank. Therefore, it requires an analysis of the financial performance of the bank to assist investors in determining investment decisions in which investors expect continuously grows profits. Financial performance can be seen from the financial statements issued by the bank which functions to determine appropriate decisions for internal and external parties (Irman and Wulansari, 2018).

Bank performance can be measured based on its level of profitability. It uses Return on Assets (ROA) to measure the level of profit or profitability of the bank. ROA is counted by comparing the profit before tax to the total assets owned by the company. ROA focuses more on the company's ability to earn revenue through its activities or operations as a whole. Thus, the higher the value of ROA, the higher the level of return gained by the company (Wulandari, 2018). The following figure shows the average ROA of State-Owned Banks in $2009-2018$. 


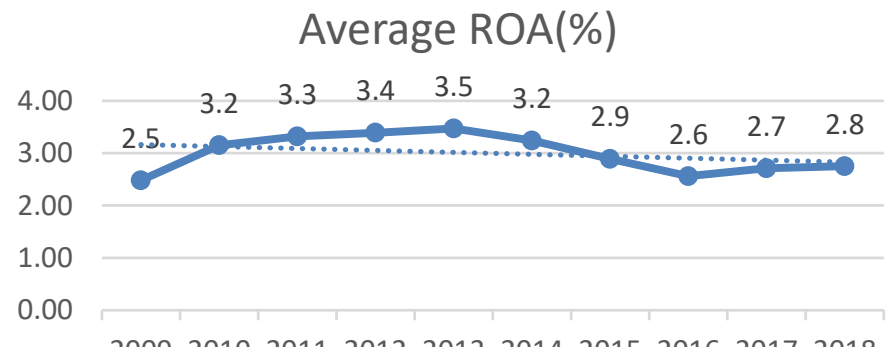

2009201020112012201320142015201620172018

$\longrightarrow$ ROA $\quad \cdots . . .$. Linear (ROA)

Figure 1. Graph of Average ROA of State-Owned Banks in the 2009-2018 Period Source: Financial Statements (processed data)

Based on Figure 1, the average ROA of state-owned banks experienced fluctuations during 2009-2018. The trendline of the above indicates a decrease. In 2009-2013, the average ROA of state-owned banks consistently increased, but it declined in 2014-2016. It is because the ROA values of Bank BRI decreased by 4.73\%, 4.19\%, and 3.84\% in 2014-2016. Besides, Bank Mandiri also experienced the same, in which its ROA values declined 3.57\%, 3.15\%, and 1.95\% in $2014-2016$. Further, the ROA values of Bank BNI also decreased to 2.64\% in 2015 and Bank BTN declined to 1.14\% in 2014. During 2014-2016, the profitability of the bank was considered under pressure. It is due to declining credit growth and declining third party funds (DPK). Besides, the increase of non-performing loans particularly of the mining sector and other commodities with weakening prices (Republika.co.id, 2015). However, in 2017-2018, the average ROA of state-owned banks has re-increased.

Fahmi (2014: 194), bank performance typically relies on the CAMEL method. It consists of 5 aspects, namely Capital, Assets, Management, Earnings, and Liquidity. They use financial ratio analysis. It uses Capital Adequacy Ratio (CAR) for capital, Nonperforming Loan (NPL) for assets, Net Interest Margin (NIM) for management, Operating Expenses to Operating Income (BOPO) for earning, and Loan to Deposit Ratio (LDR) for liquidity aspect. The result of financial ratio analysis is useful in assessing management performance in a period (Kasmir, 2015: 104).

Table 1 State-owned Banks Ratios in the 2009-2018 Period

\begin{tabular}{|l|l|l|l|l|l|l|l|l|l|l|}
\hline \multirow{2}{*}{$\begin{array}{l}\text { Average } \\
\text { Ratios }\end{array}$} & \multicolumn{10}{|c|}{ Years } \\
\cline { 2 - 12 } & 2009 & 2010 & 2011 & 2012 & 2013 & 2014 & 2015 & 2016 & 2017 & 2018 \\
\hline CAR $(\%)$ & 15,99 & 15,62 & 15,74 & 16,70 & 15,66 & 16,44 & 18,91 & 20,99 & 20,50 & 19,72 \\
\hline NPL(\%) & 3,55 & 3,13 & 2,71 & 2,61 & 2,34 & 2,33 & 2,61 & 2,95 & 2,62 & 2,42 \\
\hline NIM(\%) & 6,24 & 6,98 & 6,67 & 6,44 & 6,45 & 6,31 & 6,33 & 6,36 & 5,96 & 5,65 \\
\hline BOPO(\%) & 80,38 & 73,92 & 72,06 & 68,90 & 68,08 & 71,85 & 74,49 & 76,43 & 73,34 & 72,65 \\
\hline LDR(\%) & 76,35 & 79,80 & 80,20 & 83,98 & 90,31 & 90,09 & 92,62 & 91,68 & 91,24 & 94,49 \\
\hline ROA(\%) & 2,51 & 3,17 & 3,32 & 3,39 & 3,46 & 3,23 & 2,90 & 2,56 & 2,72 & 2,74 \\
\hline
\end{tabular}

Source: Financial Statements (processed data)

Based on table 1, state-owned banks show a tendency of relatively fluctuating CAR, NPL, LDR, NIM, BOPO, and ROA values in 2009-2018. Besides, each variable of CAR, NPL, NIM, BOPO, and LDR on ROA in 2009-2018 indicates unsuitable development. Further, a research gap between previous inconsistent research results encourages the researcher to conduct this current research.

Based on the elaborated issues above, the formulation of problems of this research cover (1) Do Capital Adequacy Ratio (CAR), Non-performing Loans (NPL), Net Interest Margin (NIM), Operating Expenses to Operating Income (BOPO), and the Loan to Deposit Ratio (LDR) partially affect the profitability of state-owned banks in the 2009-2018 period? (2) Do the Capital Adequacy Ratio (CAR), Non-performing Loans (NPLs), Net Interest Margins (NIM), Operating Expenses to Operating Income (BOPO), and Loan to Deposit Ratio (LDR) simultaneously affect the profitability of state-owned banks in the 2009-2018 period?

\section{IDENTIFY, RESEARCH AND COLLECT IDEA}

\section{Definition of Bank and its Functions}

According to Act Number 10 of 1998 concerning Banking, Bank is a business entity collecting funds from the public in the form of savings and distributes them to the public in the form of credit and or other forms to improve the standard of living of the community. Banks have three general functions and three special functions. The general functions cover collecting funds in the form of savings, distributing funds to the public in the form of credit, and financial services to improve the community's life. The special functions include agents of trust, agents of development, and agents of service. 


\section{Financial Ratio}

Kasmir (2015:104) states that the financial ratio is activities comparing the numbers in the financial statements with the implemented ones by dividing each number with another. The comparison is between one or more components of one or more financial statements in certain periods. The calculation of financial ratios can be useful for assessing the performance of company management in a period, such as the achievement of predetermined targets and management capabilities in managing company resources effectively. Capital Adequacy Ratio (CAR)

According to Fahmi (2014: 181), the Capital Adequacy Ratio (CAR) is the bank performance ratio in measuring capital adequacy owned by banks which is useful to support all activities which may cause risks. CAR is also the amount of capital related to the credit risk of assets in the bank balance (Indonesian Bankers Association, 2016:162).

$$
\mathrm{CAR}=\frac{\text { Capital }(\text { Core capital }+ \text { Complementary capital) }}{\text { Risk-Weighted Assets }(\text { ATMR })} \times 100 \%
$$

\section{Non-Performing Loan}

Taswan (2010: 164) stated that net-performing loan is the ratio of non-performing loans to total loans, in which the intended loans are loans given to third parties (excluding other banks) and non-performing loans are substandard loan, bad loans, or doubtful loans. Non-performing loans are calculated on a gross basis that is not reduced with PPAP.

$$
\mathrm{NPL}=\frac{\text { non-performing loans }}{\text { Total loans }} \times 100 \%
$$

\section{Net Interest Margin (NIM)}

Pandia (2012: 71-72) explained that the Net Interest Margin (NIM) is a useful ratio to measure the capability of bank management in managing its productive assets to obtain net interest income. The value of this ratio is considered better if it is higher as it shows an increased interest received to productive assets managed by the bank. Therefore, it provides lower problematic profitability of the bank.

$$
\mathrm{NIM}=\frac{\text { Interest income }- \text { Interest expense }}{\text { Average productive assets }} \times 100 \%
$$

\section{Operating Expense to Operating Income (BOPO)}

According to Pandia (2012: 72), BOPO is an efficiency ratio that is useful for measuring the ability of bank management in managing operating expenses to operating income. The value of this ratio is considered e better if it is smaller as it indicates higher efficiency of operating cost spent by the bank so that it has smaller problematic profitability.

$$
\mathrm{BOPO}=\frac{\text { Total operating cost }}{\text { Total operating income }} \times 100 \%
$$

\section{Loan to Deposit Ratio (LDR)}

The Indonesian Bankers Association (2018: 180) states that the Loan to Deposit Ratio (LDR) is a loan ratio given to third parties, excluding loans to other banks both in Rupiah and foreign currencies against third party funds (current accounts, savings, and deposits) both in Rupiah and foreign currencies. LDR is a comparison of loans provided to third party funds (Taswan, 2010: 167).

$$
\mathrm{LDR}=\frac{\text { Loans }}{\text { Third party funds }} \times 100 \%
$$

\section{Profitability}

Sutrisno (2012: 222) stated that profits are the acquisition of policies applied by the company management and the profit can be useful to measure and determine the level of profits gained by the company. One of the profitability ratios that can be used is Return on Assets (ROA). According to the Indonesian Bankers Association (2016: 151), profit before tax is profit contained or recorded in the financial statements of the bank income in the current year period. Meanwhile, the average total asset is the average total assets of the bank on the financial statements.

$$
\mathrm{ROA}=\frac{\text { Prof } \text { it before tax }}{\text { Average total assets }} \times 100 \%
$$

\section{Previous Research}

Some previous research regarding the relationship between CAR, NPL, LDR, NIM, BOPO ratios and the profitability (ROA) of banks show different or inconsistent results. In detail, research conducted by Stevani and Sudirgo (2019) and Irman and Wulansari (2018) found that CAR has a significant and negative effect on ROA. However, another research conducted by Syamsuddin (2013) provides different results in which CAR has a significant positive effect on ROA. Meanwhile, Hutagalung et al (2013), Wulandari (2018), and Maria (2015) found that CAR has no significant effect on ROA. Further, Yogianya (2013), Yuhasril (2019), dan Inggawati e al (2018) revealed that NPL has a significant and negative effect on ROA but Avrira and Pangestuti (2016) found that NPL has a positive effect on ROA. Other studies carried out by Maria (2015), Wulandari (2019) and Amzy et al (2019) showed that NPL has no significant effect on ROA. 
Moreover, research conducted by Maria (2015), Avrita and Pangestuti (2016), and Yuhasril (2019) revealed that NIM has a significant and positive effect on ROA. On the other hand, Syamsuddin (2013) stated that NIM has no significant effect on ROA. Maria (2015) and Hutagalung et al (2013) found that BOPO has a significant and negative effect on ROA. It is different from research conducted by Nanda et al (2019) in which BOPO has a significant and positive effect on ROA. Yogianta (2013) found that LDR has a significant positive effect on ROA but Wulandari (2018), Maria (2015), Stevani and Sudirgo (2019), and Hutagalung et al (2013) found that LDR has no significant effect on ROA. Further, Amzy et al (2019) and Inggawati (2018) revealed that LDR shows a negative effect on ROA.

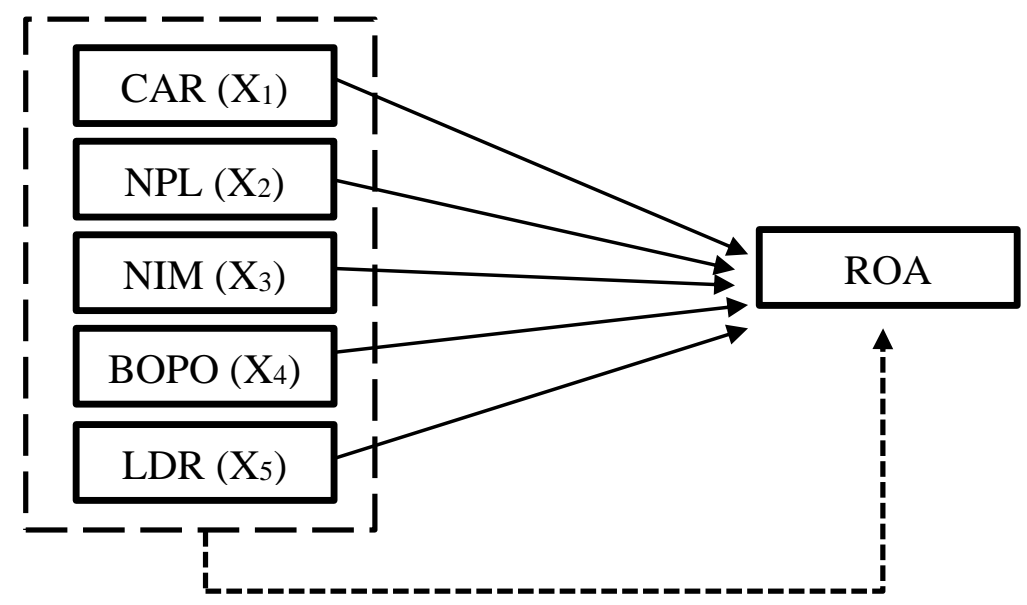

Figure 2. Framework of Hypothesis

Notes:

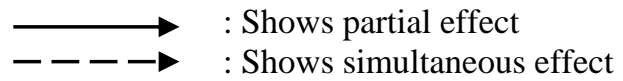

\section{Research Hypothesis}

A hypothesis is a logically predicted relationship between two or more variables and it is in the form of statements and can be tested (Sekaran, 2006:135). Based on the elaborated theories above and the results of previous research, the researcher formulated the following hypotheses:

$\mathrm{H}_{1}$ : CAR significantly affects the profitability (ROA)

$\mathrm{H}_{2}$ : NPL significantly affects the profitability (ROA)

$\mathrm{H}_{3}$ : NIM significantly affects the profitability (ROA) of state-owned banks

$\mathrm{H}_{4}$ : BOPO significantly affects the profitability (ROA)

$\mathrm{H}_{5}$ : LDR significantly affects the profitability (ROA)

$\mathrm{H}_{6}$ : CAR, NPL, NIM, BOPO, and LDR significantly affect the profitability (ROA)

This research is quantitative and aims to analyze the effect of CAR, NPL, NIM, BOPO, dan LDR ratios on the profitability of state-owned banks in 2009-2018. Based on the aims, this study is descriptive and verification. The sample was selected using a nonprobability sampling technique in which this study used all members of the population as samples. The sample covered Bank Rakyat Indonesia, Bank Mandiri, Bank Negara Indonesia, and Bank Tabungan Negara that published financial reports and annual reports in the 2009 - 2018 period. It used secondary data from the financial reports and annual report of each bank's official website.

\section{Data Analysis Method}

This study used descriptive statistic tests, classical assumption test, panel data regression analysis, coefficient of determination test (R2), simultaneous test (F-test), and partial test ( $\mathrm{T}$ - test). Descriptive statistics are useful for providing a general description of the data obtained including maximum, minimum, mean, and standard deviation (standard) values. Before the data were processed, the researcher performed the classical assumptions test to ensure that the data were valid and could be processed. The researcher used the classical assumption test on normality test, multicollinearity test, heteroscedasticity test, and autocorrelation test. The collected data were then analyzed using panel data regression method. The panel data regression model equation is as follows:

$$
\mathrm{Y}_{\mathrm{it}}=\beta_{0}+\beta_{1} \mathrm{X}_{1 \mathrm{it}}+\beta_{2} \mathrm{X}_{2 \mathrm{it}}+\beta_{3} \mathrm{X}_{3 \mathrm{it}}+\beta_{4} \mathrm{X}_{4 \mathrm{it}}+\beta_{5} \mathrm{X}_{5 \mathrm{it}}+\varepsilon_{\mathrm{it}}
$$




\section{RESULT AND DISCUSSION}

\section{Result of Descriptive Statistics Tests}

Table 2 Descriptive Statistics

\begin{tabular}{|l|l|l|l|l|l|l|}
\hline & CAR & NPL & NIM & BOPO & LDR & ROA \\
\hline Maximum & 22.96 & 4.68 & 10.77 & 88.97 & 108.86 & 5.15 \\
\hline Minimum & 13.20 & 1.55 & 4.32 & 59.93 & 59.15 & 1.14 \\
\hline Mean & 17.6272 & 2.7260 & 6.3365 & 73.2082 & 87.0737 & 3.0000 \\
\hline Std. Deviation & 2.6934 & 0.8380 & 1.5081 & 7.9862 & 12.8222 & 1.0763 \\
\hline Observations & 40 & 40 & 40 & 40 & 40 & 40 \\
\hline
\end{tabular}

Source: Output EViews 10 Student Lite Version (processed data)

Based on table 2, the Capital Adequacy Ratio (CAR) variable has a mean value of 17.63\%. The maximum value of the CAR variable reaches $22.96 \%$ in 2017 and a minimum value of $13.20 \%$ in 2009 at Bank BRI. Based on Bank Indonesia Regulation Number $15 / 12 / \mathrm{PBI} / 2013$, the minimum limit of CAR for a bank is $8 \%$. The mean value of the CAR ratio is $17.63 \%$ which is higher than the minimum limit set by Bank Indonesia. Therefore, it can be said that the CAR of state-owned banks is considered good. CAR variable has a standard deviation value of $2.69 \%$ in which it is lower than the mean value of $17.63 \%$. It indicates that the CAR variable has a low deviation level and the data are less varied or relatively homogeneous.

The Non-performing loan (NPL) variable of state-owned banks has a mean value of $2.73 \%$. The maximum value of the NPL variable reaches $4.68 \%$ in 2009 with a minimum value of $1.55 \%$ in 2013 at Bank BRI. Based on Bank Indonesia Regulation Number $17 / 11 / \mathrm{PBI} / 2015$, the maximum limit of the NPL ratio is 5\%. The mean value of the NPL ratio is $2.73 \%$ which is lower than the maximum limit set by Bank Indonesia. Thus, it can be said that the NPL ratio of state-owned banks is relatively good. The NPL variable has a standard deviation of $0.84 \%$ which is lower than the mean value of $2.73 \%$. It indicates that the NPL variable has a low deviation level and the data are less varied or relatively homogeneous.

The Net Interest Margin (NIM) variable of the state-owned bank has an average value of $6.34 \%$. The maximum value on the NIM variable is $10.77 \%$ in 2010 at Bank BRI with the minimum value of $4.32 \%$ in 2018 at Bank BTN. Based on the Circular Letter of Bank Indonesia Number 6/23/DPNP 2004 the minimum value of NIM is $2 \%$. The mean value of NIM is $6.34 \%$ which is higher than the minimum limit set by Bank Indonesia. The NIM variable has a standard deviation of $1.51 \%$ which is lower than the mean value. It shows that the NIM variable has a low deviation level and the data are less varied or relatively homogeneous.

The Operating Expenses to Operating Income (BOPO) variable of state-owned banks have a mean value of $73.21 \%$. The maximum value on the BOPO variable is $88.97 \%$ in 2014 at Bank BTN with the minimum value of 59.93\% in 2012 at Bank BRI. Based on the Circular Letter of Bank Indonesia Number 6/23/DPNP 2004, the maximum value of BOPO is $94 \%$ - 96\%. The standard deviation value in table 2 is $7.99 \%$ which is lower than the mean value of $73.21 \%$. It indicates that the BOPO variable has a low deviation level and the data are less varied or relatively homogeneous.

The Loan to Deposit Ratio (LDR) variable of state-owned banks has a mean value of $87.07 \%$. The maximum value of the LDR variable is $108.86 \%$ in 2014 at Bank BTN with the minimum value of 59.15\% in 2009 at Bank BRI. Based on Bank Indonesia Regulation Number 17/11/PBI/2015, the interval of the LDR is $78 \%$ - 92\%. The mean value of LDR is $87.07 \%$ which is within the interval. Therefore, the LDR ratio of state-owned banks is quite good. The LDR variable has a standard deviation of $12.82 \%$ which is smaller than the mean value of $87.07 \%$. It shows that the LDR variable has a low deviation level and the data are less varied or relatively homogeneous.

The Return on Asset (ROA) variable of state-owned banks has a mean value of 3\%. Based on Bank Indonesia Regulations, the minimum value of the ROA ratio is $1.5 \%$. It is higher than the minimum value set by Bank Indonesia. Thus, it can be said that the ROA of state-owned banks is good. The maximum value of the ROA variable is 5.15\% in 2012 at Bank BRI and the minimum value of $1.14 \%$ in 2014 at Bank BTN. The standard deviation value in table 2 is $1.08 \%$ which is lower than the mean value of 3\%. It indicates that the ROA variable has a low deviation level and the data are less varied or relatively homogeneous.

\section{Classical Assumption Tests}

\section{Normality Test}

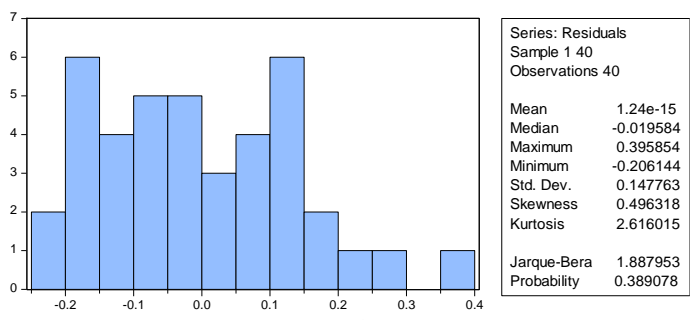

Figure 3 Result of Normality Test

Source: Output EViews 10 Student Lite Version (processed data)

This publication is licensed under Creative Commons Attribution CC BY.

http://dx.doi.org/10.29322/IJSRP.10.07.2020.p10384

WWW.ijsrp.org 
Based on Figure 3, the Jarque-Bera Normality test statistic result is 1.887953 and it is significant with the probability value of 0.389078 . Thus, the probability value is higher than the significant level $(\alpha=5 \%)$ meaning that it is not significant. Therefore, it can be concluded that the residuals are normally distributed.

\section{Multicollinearity Test}

\section{Table 3 Result of Multicollinearity Test}

\begin{tabular}{|c|c|c|c|}
\hline Variable & $\begin{array}{l}\text { Coefficient } \\
\text { Variance }\end{array}$ & $\begin{array}{c}\text { Uncentered } \\
\text { VIF }\end{array}$ & $\begin{array}{c}\text { Centered } \\
\text { VIF }\end{array}$ \\
\hline C & 0.181847 & 290.4359 & NA \\
\hline CAR & 0.000102 & 51.82356 & 1.153435 \\
\hline NPL & 0.003185 & 41.28903 & 3.483455 \\
\hline NIM & 0.000370 & 25.05083 & 1.311104 \\
\hline BOPO & 5.40E-05 & 467.8002 & 5.365535 \\
\hline LDR & $8.45 \mathrm{E}-06$ & 104.5477 & 2.164627 \\
\hline
\end{tabular}

Source: Output EViews 10 Student Lite Version (processed data)

Table 3 presents the relationship or correlation between independent variables. Based on the results of the multicollinearity test, the VIF value is lower than 10. The VIF values range from 1.153435 to 5.365535 . It shows that there is no multicollinearity in the regression model used.

\section{Heteroscedasticity Test}

\section{Table 4 Result of Heteroscedasticity Test}

\begin{tabular}{|c|c|c|c|}
\hline F-statistic & 1.266222 & Prob. $F(5,34)$ & 0.3010 \\
\hline Obs ${ }^{*} R$-squared & 6.279132 & Prob. Chi-Square(5) & 0.2800 \\
\hline Scaled explained SS & 4.189627 & Prob. Chi-Square(5) & 0.5225 \\
\hline
\end{tabular}

Source: Output EViews 10 Student Lite Version (processed data)

Based on the results of the Glejser heteroscedasticity test in table 4, the value of Obs*R-squared is 6.279132 with a Chi-Square probability of 0.2800 . The probability value of Chi-Squared is higher than the significant level $(\alpha=5 \%)$ meaning that it is not significant. Therefore, it can be concluded that there are no heteroscedasticity issues in the model used in this research and the model can produce a BLUE (Best Linear Unlock Estimator) estimator.

\section{Autocorellation Test}

\section{Table 5 Result of Autocorellation Test}

Breusch-Godfrey Serial Correlation LM Test:

Null hypothesis: No serial correlation at up to 2 lags

\begin{tabular}{lclc}
\hline \hline F-statistic & 0.951054 & Prob. $\mathrm{F}(2,32)$ & 0.3970 \\
Obs*R-squared & 2.244236 & Prob. Chi-Square $(2)$ & 0.3256 \\
\hline \hline \multicolumn{2}{c}{ Source: Output EViews 10 Student Lite Version (processed data) }
\end{tabular}

Based on the result of the LM test of Breusch-Godfrey statistics in table 5, the value of Obs*RSquared is 2.244236 with a Chi-Squared Probability of 0.3256 . The Chi-Squared probability value is higher than the significant level $(\alpha=5 \%)$ meaning that it is not significant. Therefore, it can be concluded that there are no autocorrelation issues in the model used in this research. 


\section{Selection of Panel Data Model}

The Chow Test aims to determine the most appropriate or best model among the common effect or fixed-effect models. The hypotheses that can be used in this test are as follows:

Ho: Common Effect Model

$\mathrm{H}_{\mathrm{a}}$ : Fixed Effect Mode

If the probability (F-statistic) is $<0.05$, then $\mathrm{H}_{0}$ is rejected meaning that the fixed effect model is considered better than the common effect model. On the other hand, if the probability (F-statistic) is $>0.05$, then $\mathrm{H}_{0}$ is accepted meaning that the common effect model because is considered better than the fixed effect model.

Table 6 Chow Test

\begin{tabular}{|c|c|c|c|}
\hline Effects Test & Statistic & d.f. & Prob. \\
\hline Cross-section F & 6.661374 & $(3,31)$ & 0.0013 \\
\hline Cross-section Chi-square & 19.901081 & 3 & 0.0002 \\
\hline
\end{tabular}

Source: Output EViews 10 Student Lite Version (processed data)

Based on the results of the Chow test in table 6, it can be seen that the probability value of Cross-section $\mathrm{F}$ is $0.0013<0.05$. Based on the data above, it can be decided that $\mathrm{H}_{0}$ is rejected and the model used in this study is the fixed effect model.

\section{Panel Data Regression}

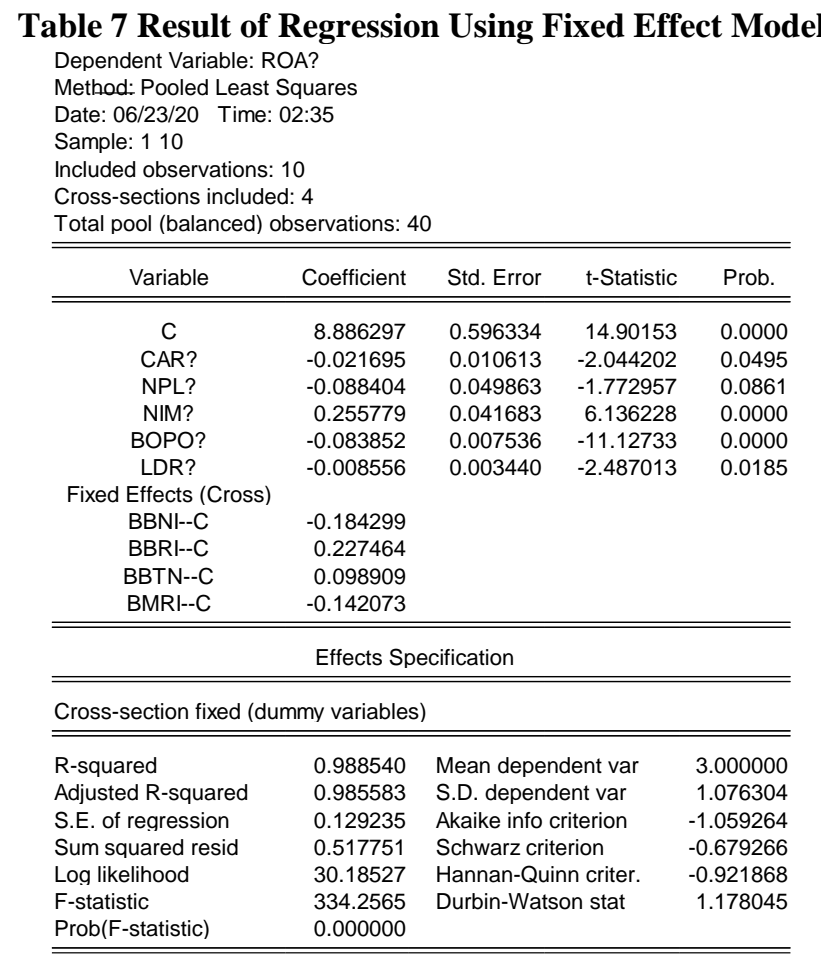

Source: Output EViews 10 Student Lite Version (processed data)

This panel data regression equation explains the effect of Capital Adequacy Ratio (CAR), Non-performing Loans (NPL), Net Interest Margin (NIM), Operating Expenses to Operating Income (BOPO), and Loan to Deposit Ratio (LDR) on ROA of state-owned banks in the $2009-2018$ period as follows:

$$
\mathrm{Y}=8,886297-0,021695 \mathrm{CAR}_{\mathrm{it}}-0,088404 \mathrm{NPL}_{\mathrm{it}}+0,255779 \mathrm{NIM}_{\mathrm{it}}-0,83852 \mathrm{BOPO}_{\mathrm{it}}-008556 \mathrm{LDR}_{\mathrm{it}}+\varepsilon_{\mathrm{it}}
$$




\section{Coefficient of Determination Test $\left(\mathbf{R}^{2}\right)$}

According to Ghozali (2017: 55), the coefficient of determination (R2) is useful to measure the ability of the model in the variation of the dependent variable. The coefficient of determination is between $0-1$. The smaller the value of the coefficient of determination (R2), the more limited the ability of independent variables in explaining the variation of the dependent variable. The coefficient of determination (R2) closes to 1 means that the independent variables provide almost all information needed in predicting the variation of the dependent variable. Based on the regression result in table 7, it can be seen that the Adjusted R-Squared value is 0.9855 or $98.55 \%$. It means that the independent variables of CAR, NPL, NIM, BOPO, and LDR can explain or affect the dependent variable of ROA of state-owned banks in 2009-2018 of 98.55\% and the rest of $1.45 \%$ can be explained by other variables outside the research.

\section{Simultaneous Test (F-test)}

Simultaneous test or F-test is required to determine whether all independent variables have a simultaneous effect on the dependent variable (Ghozali, 2017: 56). If the F-statistical probability value is $<\alpha(0.05)$, then $\mathrm{H}_{0}$ is rejected. On the other hand, if the F-statistical probability value is $>\alpha(0.05)$, then $\mathrm{H}_{0}$ is accepted. Based on table 7, it can be seen that the statistical $\mathrm{F}$ value is 334.2565 and the F-statistical probability value is 0.0000 which is lower than the significance level of $0.05(0.000<0.05)$. Based on these data, it can be seen that $\mathrm{H}_{0}$ is rejected indicating that CAR, NPL, NIM, BOPO, and LDR simultaneously have a significant effect on profitability proxied by ROA in state-owned banks in the 2009-2018 period.

\section{Partial Test (T-test)}

In general, the partial test or T-test is to find out the relationship between each independent variable and the dependent variable. If the t-statistic probability value is $<\alpha(0.05)$, then $\mathrm{H}_{0}$ is rejected but if the t-statistic probability value is $>\alpha(0.05)$, then $\mathrm{H} 0$ is accepted. Based on table 7, it can be seen that the probability value (t-statistic) of the CAR variable is lower than the significance level $(0.0495$ $<0.05)$. Based on these data, it can be concluded that $\mathrm{H}_{0}$ is rejected. It means that the CAR variable partially has a significant and negative effect on the ROA of state-owned banks in 2009-2018. The probability value (t-statistic) of NPL variable is higher than the significance level $(0.0861>0.05)$. Thus, it can be concluded that $\mathrm{H}_{0}$ is accepted meaning that the NPL variable partially has no significant affect the ROA of state-owned banks in 2009-2018.

The probability value (t-statistic) of NIM variable is lower than the significance level $(0,000<0.05)$. Therefore, it can be concluded that $\mathrm{H}_{0}$ is rejected. It means that the NIM variable partially has a significant and positive effect on the ROA of state-owned banks in 2009-2018. The probability value (t-statistic) of BOPO variable is lower than the significance level $(0,000<0.05)$. Thus, it can be concluded that $\mathrm{H}_{0}$ is rejected meaning that the BOPO variable partially has a significant and negative effect on the ROA of the stateowned bank in 2009-2018. The LDR variable has a probability value (t-statistic) smaller than the significance level $(0.0185<0.05)$. So, it can be concluded that $\mathrm{H}_{0}$ is rejected which means that the LDR variable partially has a significant and negative effect on the ROA of state-owned banks in 2009-2018.

\section{The Effect of Capital Adequacy Ratio on Profitability (Return on Assets)}

Based on the regression result in table 7, the coefficient of the CAR variable is -0.021695 meaning that an increase in CAR values of $1 \%$ with the assumption that other variables are constant or zero, then the ROA of the state-owned banks decrease by 0.021695 or negatively affect. Based on table 7 , the result of the partial test or t-test showed that the probability value (t-statistic) of CAR is 0.0495 which is lower than the significance value $(0.0495<0.05)$ so that $\mathrm{H}_{0}$ is rejected. Then, it can be concluded that the CAR variable partially has a significant and negative effect on ROA of state-owned banks in the 2009-2018 period.

The result of this study indicates that any increase in CAR will cause a decrease in ROA. It is because of the Risk-Weighted Assets (RWA) contains assets with the highest risk from loans. If loans increase, it will affect the increase in total RWA. It can cause a decrease in the CAR value in the bank. Loans also provide great contributions to the bank in which the increase of loans will cause an increase in bank interest income. Therefore, the decrease in CAR value caused by an increase in loans can affect the increase in bank income. It also affects the profit before tax or ROA. The result of this research is in line with the previous research conducted by Stevani and Sudirgo (2019) and Irman and Wulansari (2018).

\section{The Effect of Non-performing Loans on Profitability (Return on Assets)}

Based on the regression result in table 7, the coefficient of the NPL variable is -0.088404 meaning that an increase in NPL values of $1 \%$ with the assumption that other variables are constant or zero, then the ROA of the state-owned bank decrease by 0.088404 or have a negative effect. In the result of partial test or t-test in table 7, the probability value (t-statistics) of NPL is 0.0861 which is higher than the significance value $(0.0861>0.05)$, so that $\mathrm{H}_{0}$ is accepted. Therefore, the NPL variable does not significantly affect the ROA of state-owned banks in 2009-2018.

The result of this research is contradicted with the hypothesis that NPL has a significant effect on ROA. It is because the stateowned bank samples have a low credit risk value which is below the maximum limit of 5\% set by Bank Indonesia. Therefore, the low credit risk value will not affect the profit or cause an increase in ROA. State-owned banks also have a relatively high capital so that the risks can be covered with the capital owned by the banks. On the other hand, the result of this study is in line with previous research conducted by Irman and Wulansari (2018), Amzy et al (2019), Maria (2015), Stevani and Sudirgo (2019), and Wulandari (2018). 


\section{Effect of Net Interest Margin on Profitability (Return on Assets)}

Based on the regression result in table 7, the coefficient of the NIM variable is 0.255779 . It means that if there is an increase in the NIM of $1 \%$ with the assumption that the other variables are constant or zero, then the ROA of the state-owned banks increases by 0.255779 or have a positive effect. The result of the partial test or t-test in table 7 showed that the probability value (t-statistic) of NIM is 0.0000 which is higher than the significance value $(0.0000<0.05)$ so that $\mathrm{H}_{0}$ is rejected. Thus, the NIM variable partially has a significant and positive effect on ROA of state-owned banks in 2009-2018.

The result of this research is in line with the proposed hypothesis in which there is a significant relationship between NIM and ROA. If the provision of loans by a bank's management is prudent, then the quality of its productive assets will be maintained. Good quality of productive assets will increase the net interest income obtained from the provision of loans. This can cause bank profits to increase, including the level of income of the total assets. Hence, the increase in profits obtained will increase financial performance too. The result of this research supports the previous research conducted by Maria (2015), Irman and Wulansari (2018), Wulandari (2018), Yuhasril (2019), and Hutagalung et al (2013).

\section{Effect of Operating Expenses to Operating Income on Profitability (Return on Assets)}

Based on the result of regression in table 7, the coefficient of BOPO variable is -0.083852 . It means that if there is an increase of $1 \%$ of the BOPO with the assumption that other variables are constant or zero, then the ROA of the state-owned banks decrease by 0.083852 or negatively affect. The result of the partial test or t-test in table 7 showed the probability value (t-statistic) of BOPO of 0.0000 or lower than the significance value $(0.0000<0.05)$ so that $\mathrm{H}_{0}$ is rejected. Thus, the BOPO variable partially has a significant and negative effect on ROA of the state-owned banks in 2009-2018.

Based on table 2, the mean value of BOPO of state-owned banks in 2009-2018 is $73.21 \%$. It indicates that the performance of state-owned banks in managing its operations or business in 2009-2018 has been effective and efficient. The higher the BOPO value, the less efficient in managing its operating expenses, and it is followed by a decrease in operating income and affect the profit before tax obtained by the bank. The lower the BOPO value, the more efficient and better the performance of the management of a bank in carrying out its operations. Thus, the opportunity to obtain profits also increases. The increase in profits affects the ROA of the bank. The result of this research is in line with research conducted by Maria (2015), Irman and Wulansari (2018), Wulandari (2018), Stevani and Sudirgo (2019), Syamsuddin (2013), Hutagalung, et al (2013), and Yogianta (2013) in which there is a negative effect of BOPO on ROA.

\section{The Effect of Loan to Deposit Ratio on Profitability (Return on Assets)}

Based on the result of regression in table 7, the coefficient of the LDR variable is -0.008556 . It means that if the LDR increases by $1 \%$ with the assumption of other variables are constant or zero, then the ROA of state-owned banks decreases by 0.008556 or negatively affect. The result partial test or t-test in table 7 showed the LDR probability value (t-statistic) of 0.0185 which is higher than the significance value $(0.0185<0.05)$ so that $\mathrm{H}_{0}$ is rejected. Therefore, the LDR variable partially has a significant and negative effect on ROA of state-owned banks 2009-2018.

The result of this research revealed that any increase in LDR causes a decrease in ROA. It occurs because the LDR ratio of state-owned banks continues to increase each year and reaches the peak in 2018. The higher the LDR ratio, the lower the condition of bank liquidity. Banks are considered unable to meet the obligation to pay funds to customers for distributed loans. Banks need to be careful in providing or using funds. An increase in the LDR of a bank can also be caused by the provision of credit on a high scale without followed with a high return rate of non-performing loans. The less optimal use of funds makes banks difficult to earn profits and finally decrease its profitability. The result of this research is in line with the previous research conducted by Inggawati et al (2018) and Amzy et al (2019).

\section{CONCLUSION}

Based on the discussion of the result of data analysis with panel data regression test, it can be concluded that:

1. Simultaneous test (F-test) shows that the Capital Adequacy Ratio (CAR), Non-performing Loans (NPL), Net Interest Margin (NIM), Operating Expenses to Operating Income (BOPO), and Loan to Deposit Ratio (LDR) simultaneously has a significant effect on the profitability of state-owned banks in the 2009-2018 period.

2. Partial test (t-test) shows that the Capital Adequacy Ratio (CAR), Operating Expenses to Operating Income (BOPO), and Loan to Deposit Ratio (LDR) variables partially have a significant negative effect on ROA of state-owned banks in the 2009-2018 period. The Non-performing Loan (NPL) variable partially does not significantly affect the ROA of state-owned banks in the 2009-2018 period. The Net Interest Margin (NIM) variable partially has a significant positive effect on ROA of state-owned banks in the 2009-2018 period.

\section{SUGGESTION}

The researcher provides some suggestions related to research in financial institutions and other market actors as follows: 
1. For banks, to increase the profitability value by observing the NIM variable because it has a positive and significant effect. State-owned banks have to consider it and maintain the NIM values higher the minimum limit as set by Bank Indonesia. In addition, it has to consider CAR, BOPO, and LDR variables that have a negative and significant effect to maintain within the limits set by Bank Indonesia.

2. For investors, to look at the information contained in the research and carefully select the company. Investors have to consider the level of loan risk for a bank, the level of capital adequacy, the level of liquidity, and the company's ability to regulate the level of operating cost efficiency before investing

\section{REFERENCES}

[1] Amzy, A., Febriansyah, I., \& Munir, A. (2019). "The Effect of Financial Performance Ratios on Conventional Bank Profitability in Indonesia Stock Exchange". Ekuilibrium: Jurnal Ilmiah Bidang Ilmu Ekonomi, Vol 14, No.2, pp. 84-103.

[2] Avrita, R.D., \& Pangestuti, I. R. D. (2016). "Analisis Pengaruh CAR, NPL, LDR, NIM, dan BOPO Terhadap Profitabilitas Bank". Diponegoro Journal of Management, Vol. 5, No 2, pp 1-13.

[3] Bank Indonesia. (2004). Surat Edaran Bank Indonesia No.6/ 23 /DPNP tanggal 31 Mei 2004. Jakarta: Bank Sentral Republik Indonesia

[4] Bank Indonesia. (2011). Peraturan Bank Indonesia Nomor 13/11/PBI/2011 Tentang Penilaian Tingkat Kesehatan Bank Umum. Jakarta: Bank Sentral Republik Indonesia

[5] Bank Indonesia. (2013). Peraturan Bank Indonesia Nomor 15/12/PBI/2013 Tentang Kewajiban Penyediaan Modal Minimum Bank Umum. Jakarta: Bank Sentral Republik IndonesiaB

[6] Bank Indonesia. (2015). Peraturan Bank Indonesia Nomor 17/11/PBI/2015 Tentang Perubahan Atas Peraturan Bank Indonesia Nomor 15/15/PBI/2013 Tentang Giro Wajib Minimum Bank Umum Dalam Rupiah Dan Valuta Asing Bagi Bank Umum Konvensional. Jakarta: Bank Sentral Republik Indonesia

[7] Brigham, E. F., \& Houston, J. F. (2013). Dasar-Dasar Manajemen Keuangan. Edisi 1, Buku 1 Jakarta. Salemba Empat

[8] Darmawi, H. (2011). Manajemen Perbankan. Cetakan 1. Jakarta. Bumi Aksara

[9] Dosen Perbanas. (nd). Capital Adequacy Ratio (CAR). https://dosen.perbanas.id/car-capital-adequacy-ratio/?print=print

[10] Fahmi, F. (2014). Pengantar Perbankan Teori dan Aplikasi. Cetakan 1. Bandung. Alfabeta

[11] Ghozali, I., dan Ratmono, D. (2017). Analisis Multivariate dan Ekonometrika Teori, Konsep, dan Aplikasi dengan Eviews 10. Edisi 2, Cetakan 2. Semarang. Badan Penerbit-Undip

[12] Hutagalung, E.N., Djumhair., \& Ratnawati, K. (2011). “Analisa Rasio Keuangan terhadap Kinerja Bank Umum di Indonesia”. Jurnal Aplikasi Manajemen, Vol. 11, No.1, pp. 122-130.

[13] Ikatan Bankir Indonesia. (2016) Manajemen Kesehatan Bank Berbasis Risiko. Jakarta. Gramedia Pustaka Utama

[14] Ikatan Bankir Indoneisa. (2018). Memahami Bisnis Bank. Edisi 2, Cetakan 7. Jakarta. Gramedia Pustaka Utama

[15] Indrawati. (2015). Metode Penelitian Manajemen dan Bisnis Konvergensi Teknologi Komunikasi dan Informasi (Cet.1). Bandung: Refika Aditama

[16] Inggawati, R., Lucy., \& Hermanto, B. (2018). "The Influence of Loan to Deposit Ratio, Loan Operational of Income Operational and Non-Performing Loan toward Profitability of Bank Perkreditan Rakyat in Sidoarjo Regency”. International Journal of Scientific and Research Publications, Vol. 8, No.11, pp. 510-519.

[17] Irman, M., \& Wulansari, V. (2018). "Analisis Pengaruh Rasio CAMEL Terhadap Kinerja Keuangan Perbankan pada Bank yang Terdaftar di Bursa Efek Indonesia” Tahun 2011-2016. Bilancia: Jurnal Ilmiah Akuntansi, Vol. 2, No. 2, pp. 182-194.

[18] Kasmir. (2015). Analisis Laporan Keuangan. Edisi 1, Cetakan 8. Jakarta. Rajagrafindo

[19] Kasmir. (2017). Bank dan Lembaga Keuangan Lainnya . Edisi Revisi, Cetakan 18. Jakarta. Rajagrafindo

[20] Katadata. (2017, 24 Februari). 2016, Laba Bank-Bank BUMN Turun 4,72 Persen [online]. Diambil dari https://databoks.katadata.co.id/datapublish/2017/02/24/2016-laba-bank-bumn-turun-472-persen [28 Novermber 2019]

[21] Maria, A. (2015). "Pengaruh CAR, BOPO, NIM, NPL, Dan LDR Terhadap ROA: Studi Kasus Pada 10 Bank Terbaik Di Indonesia Periode 2007-2011". Calyptra: Jurnal Ilmiah Mahasiswa Universitas Surabaya, Vol. 4, No. 1, pp. 1-19.

[22] Nanda, A. S., Hasan, A. F., \& Aristyanto, E. (2019). "Pengaruh CAR dan BOPO Terhadap ROA pada Bank Syariah pada Tahun 2011-2018". Islamic Banking and Finance Journal, Vol. 3, No. 1, pp. 19-31.

[23] Nazir, M. (2011). Metode Penelitian. Jakarta. Ghalia Indonesia

[24] Otoritas Jasa Keuangan. (n.d). Bank Umum. Diambil dari https://www.ojk.go.id/id/kanal/perbankan/Pages/Bank-Umum.aspx

[25] Otoritas Jasa Keuangan. (n.d). Direktori Perbankan Indonesia Bank Perserp. Diambil dari https://www.ojk.go.id/id/kanal/perbankan/data-dan-statistik/direktoriperbankan-indonesia/bank-persero/default.aspx

[26] Pandia, F. (2012). Manajemen Dana dan Kesehatan Bank. Jakarta. Rineka Cipta

[27] Republika. (2015, 01 Juni). Profitabilitas Bank Dalam Tekanan [online]. Diambil dari https://www.republika.co.id/berita/koran/pareto/15/06/01/np9a882profitabilitas-bank-dalam-tekanan [02 Desember 2019]

[28] Sekaran, U. (2006). Metodologi Penelitian untuk Bisnis. Edisi 4, Buku 1. Jakarta. Salemba Empat

[29] Sekaran, U. (2011). Metodologi Penelitian untuk Bisnis. Edisi 4, Buku 1. Jakarta. Salemba Empat

[30] Sriyana, J. (2014). Metode Regresi Data Panel. Edisi 1, Cetakan 1. Yogyakarta. Ekonisia

[31] Stevani \& Sudirgo. (2019). “Analisis CAR, BOPO, NPL, dan LDR Terhadap ROA Perusahaan Perbankan”. Jurnal Paradigma Akuntansi, Vol. 1, No. 3, pp. 863871.

[32] Sugiyono. (2015). Metode Penelitian Kuantitatif, Kualitatif, dan R\&D. Bandung, Indonesia. Alfabeta

[33] Sujarweni, V. W. (2015). Metodologi Penelitian Bisnis dan Ekonomi. Cetakan 1. Yogyakarta. Pustaka Baru Press

[34] Supardi. (2016). Aplikasi Statistika Dalam Penelitian Konsep Statistika Yang Lebih Komprehensif.Edisi Revisi, Cetakan 1. Jakarta. Change Publication

[35] Sutrisno. (2012). Manajemen Keuangan Teori, Konsep, dan Aplikaii. Edisi 1, Cetakan 7. Yogyakarta. Ekonisia

[36] Syamsuddin. (2013). "Pengaruh Capital Adequacy Ratio (CAR), Non Performing Loan (NPL), Biaya Operasional Pendapatan Operasional (BOPO), Loan to Deposit Ratio (LDR), dan Net Interest Margin (NIM) Terhadap Profitabilitas (ROA)”. Business and Management Journal, Vol. 10, No. 1, pp. 1-14.

[37] Taswan. (2010). Manajemen Perbankan Konsep, Teknik, dan Aplikasi. Edisi 2. Yogyakarta. UPPSTIM YKPN

[38] Widarjono, A. (2013). Ekonometrika Pengantar dan Aplikasi Disertai Panduan Eviews. Edisi 4. Yogyakarta. UPP STIM YKPN

[39] Wulandari. (2018). "Pengaruh Rasio CAMEL Terhadap Profitabilitas (ROA) Pada Perusahaan Perbankan Yang Terdaftar Di Bursa Efek Indonesia". Jurnal Manajemen Bisnis Indonesia (JMBI), Vol. 7, No. 5, pp. 512-522.

[40] Yogianta, C. W. (2013). "Analisis Pengaruh CAR, NIM, LDR, NPL Dan BOPO Terhadap Profitabilitas Studi Pada Bank Umum Yang Go Publik Di Bursa Efek Indonesia Periode Tahun 2002-2010”. Jurnal Bisnis Strategi, Vol. 22, No. 2, pp. 94-111.

[41] Yuhasril. (2019). "The Effect of Capital Adequacy Ratio (CAR), Non Performing Loan (NPL), Operational Efficiency (BOPO), Net Interest Margin (NIM), and Loan to Deposit Ratio (LDR), on Return on Assets (ROA)". Reseach Journal of Finance and Accounting, Vol. 10, No. 10, pp. 166-176. 


\section{AUTHORS}

First Author - Chintia Sianturi, Undergraduate, Bachelor of Management and Business, Telkom University, Indonesia. Email: chintiasianturi@gmail.com

Second Author - Dadan Rahadian, Department of Management Business Telecomunication and Informatic, School of Economic and Business, Telkom University, Indonesia. E-mail: dadan.rahadian@telkomuniversity.ac.id 